\title{
STATUTORY UTILITY RIGHTS TO REALISE ACCESS TO SERVICES AS A CHARACTERISTIC OF ADEQUATE HOUSING
}

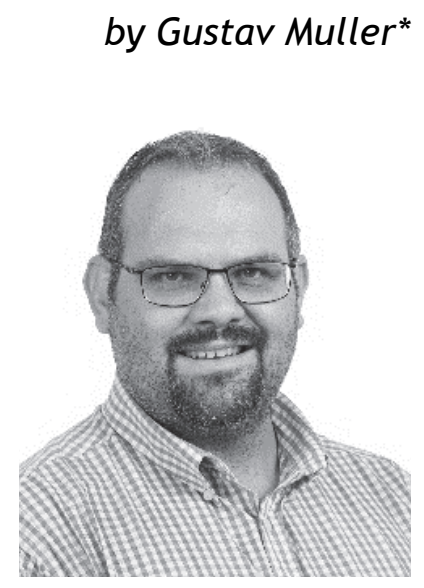

\section{Introduction}

Government of the Republic of South Africa $v$ Grootboom ${ }^{1}$ ('Grootboom') is a landmark judgment for the interpretation of the right of access to adequate housing in South Africa. In this case the Constitutional Court was confronted with the intolerable and exigent housing needs of Ms Irene Grootboom and her fellow respondents in the Wallacedene community. The community had no access to potable water and sanitation services, the municipality did not collect their domestic refuse, and very few of the informal structures had access to electricity. ${ }^{2}$ Many members of the community applied for access to low-cost subsidised housing from the Oostenberg Municipality and had been in the housing queue for almost seven years. Despite their actions they faced the prospect of enduring these intolerable conditions indefinitely. Since this prospect was unbearable, the respondents moved out of their waterlogged informal settlement onto a vacant, privately-owned property above the flood line where they erected their informal structures. ${ }^{3}$ They were

* LLB, LLD (Stell), Diploma (Åbo Akademi). Senior Lecturer, Department of Private Law, University of Pretoria. ORCID: 0000-0003-1254-6601.

12001 (1) SA 46 (CC).

2 Grootboom para 7.

3 Grootboom para 8. 
subsequently evicted from the property, ${ }^{4}$ which they named 'New Rust', and then sought shelter on the sports field in Wallacedene because their stands in the informal settlement had been taken up by other people. ${ }^{5}$ Their precarious position quickly deteriorated when the first wave of winter rain flooded their hopes of surviving another cold winter in Cape Town. The respondents launched an urgent application in the Western Cape Division of the High Court, Cape Town when the municipality made an unsatisfactory offer to their plea that the municipality would meet its constitutional obligations by providing them with temporary alternative accommodation. ${ }^{6}$ In that judgment the court ordered the municipality to provide the applicants with 'tents, portable latrines and a regular supply of water'. ${ }^{7}$ It is this order that formed the basis of the appeal directly to the Constitutional Court.

In Grootboom, Yacoob J provided a nuanced exposition of the obligations that flow from section 26 of the Constitution. In his analysis the right of access to adequate housing entails 'more than bricks and mortar'. Importantly, this includes access to:

available land, appropriate services such as the provision of water and the removal of sewage and the financing of all of these, including the building of the house itself. For a person to have access to adequate housing all of these conditions need to be met: there must be land, there must be services, [and] there must be a dwelling. ${ }^{8}$

Yacoob J's description of what it means to have access to adequate housing in South Africa - in particular, services like water, refuse removal, and electricity - resembles ${ }^{9}$ one of the characteristics that the United Nations Committee on Economic, Social and Cultural Rights $^{10}$ ('CESCR') identified as being indicative of having access to housing for purposes of article $11(1)^{\uparrow 1}$ of the International Covenant

4 Grootboom para 10.

5 Grootboom para 9.

6 Grootboom para 11 with specific reference to footnote 9.

7 Grootboom v Oostenberg Municipality 2000 (3) SA BCLR 277 (C) 293A.

8 Grootboom para 35 (emphasis added).

9 Despite the 'significant' textual differences that Yacoob $\mathrm{J}$ enumerated in Grootboom para 28.

10 The committee consists of 18 experts with internationally recognised competence in the field of human rights who serve in their personal capacity for a renewable four year term. The primary task of the Committee is to assist the Economic and Social Council with its consideration of the reports that States Parties submit to the Secretary-General of the United Nations (article 16(2) of the ICSECR).

11 Article 11(1) of the ICESCR, which affords everyone the right to an adequate standard of living, reads:

'The States Parties to the Present Covenant recognize the right of everyone to an adequate standard of living for himself and his family, including adequate food, clothing and housing, and to the continuous improvement of living conditions. The States Parties will take appropriate steps to ensure the realization of this right, recognizing to this effect the essential importance of international cooperation based on free consent.' 
on Economic, Social and Cultural Rights ${ }^{12}$ ('ICESCR'). Housing, according to the CESCR, will be considered adequate if it inter alia provides access to:

certain facilities essential for health, security, comfort and nutrition. All beneficiaries of the right to adequate housing should have sustainable access to natural and common resources, safe drinking water, energy for cooking, heating and lighting, sanitation and washing facilities, means of food storage, refuse disposal, site drainage and emergency services. ${ }^{13}$

Conceptualising access to services - like water, sanitation, refuse removal, and electricity - as an integral part of the right of access to adequate housing reinforces Yacoob J's contextual approach to the interpretation of section 26 of the Constitution. ${ }^{14}$ On the one hand, the approach forges explicit textual links with sections $24,{ }^{15}$ $27(1)(b),{ }^{16} 32,{ }^{17}$ and $33^{18}$ of the Constitution. In doing so the

12993 UNTS 3. The Covenant was adopted by the General Assembly of the United Nations on 16 December 1966 and came into force on 3 January 1976. As at 19 June 2019, the Covenant has been ratified by 169 countries. South Africa signed the Covenant on 3 October 1994 and ratified it on 15 January 2015.

13 CESCR General Comment 4: The Right to Adequate Housing (Art. 11(1)), UN Doc E/C 1992/23 (1991) para 8(b).

14 Grootboom para 21.

15 Section 24 of the Constitution states that:

'Everyone has the right - (a) to an environment that is not harmful to their health or well-being; and (b) to have the environment protected, for the benefit of present and future generations, through reasonable legislative and other measures that - (i) prevent pollution and ecological degradation; (ii) promote conservation; and (iii) secure ecologically sustainable development and use of natural resources while promoting justifiable economic and social development.' See, in general, I Currie \& J De Waal The Bill of Rights Handbook (6 ${ }^{\text {th }}$ ed) (2013) chapter 24; $M$ van der Linde \& E Basson 'Environment' in S Woolman et al (eds) Constitutional Law of South Africa (2010) chapter 50; W Freedman Property Aspects of Environmental Law (forthcoming).

16 Section 27(1) of the Constitution affords everyone 'the right to have access to (b) sufficient food and water.' See, in general, I Currie \& J De Waal (n above) 592; AJ van der Walt Constitutional Property Law (2 ${ }^{\text {nd }}$ ed) (2005) 370-378; $M$ Langford et al 'Water' in S Woolman et al (eds) Constitutional Law of South Africa $\left(2^{\text {nd }}\right.$ ed) (Revision Service, May 2011) chapter 56B and M Kidd Property in Water (forthcoming).

17 Section 32(1) of the Constitution affords everyone 'the right of access to (a) any information held by the state; and any information that is held by another person and that is required for the exercise or protection of any rights.' The Promotion of Access to Information Act 2 of 2000 was enacted to give effect to section 32(2) of the Constitution. See, in general, I Currie \& J De Waal ( $\mathrm{n}$ above) chapter 30; J Klaaren and G Penfold 'Access to Information' in S Woolman et al (eds) Constitutional Law of South Africa $\left(2^{\text {nd }}\right.$ ed) (Original Service, 2002) chapter 62.

18 Section 33(1) of the Constitution affords everyone 'the right to administrative action that is lawful, reasonable and procedurally fair'. The Promotion of Administrative Justice Act 3 of 2000 was enacted to give effect to section 33(3) of the Constitution. See, in general, I Currie \& J De Waal ( $\mathrm{n}$ above) chapter 29 and $\mathrm{J}$ Klaaren \& G Penfold 'Just Administrative Action' in S Woolman et al (eds) Constitutional Law of South Africa ( $2^{\text {nd }}$ ed) (Original Service, June 2009) chapter 63; C Hoexter Administrative Law (2 ${ }^{\text {nd }}$ ed) (2012). See also G Quinot \& $S$ Liebenberg 'Narrowing the band: Reasonableness review in administrative justice and socio-economic rights jurisprudence in South Africa' (2011) 22 Stell LR 639-663 (also published in S Liebenberg \& G Quinot Law and Poverty: Perspectives from South Africa and Beyond (2012) 197-221) and IM Rautenbach 'The limitation 
conceptualisation affirms the interrelated, interconnected and mutually supporting nature of all the rights in the Bill of Rights. ${ }^{19}$ On the other hand, the approach highlights the social and historical context against which the denial of access to water, ${ }^{20}$ sanitation, 21 refuse removal, ${ }^{22}$ electricity ${ }^{23}$ (including as a source of energy for

of rights and "reasonableness" in the right to just administrative action and the rights to access to adequate housing, health services and social security' 2005 Tydskrif vir die Suid-Afrikaanse Reg 627-654.

19 See, in general, S Liebenberg Socio-economics rights: Adjudication under a transformative constitution (2010) 51-54 and the sources cited there.

20 White Paper on Housing GG 354 GN 1376 of 23 December 1994 ('White Paper') para 3.1.4(a) estimated that $25 \%$ of all functionally urban households did not have access to piped potable water supply in 1994. The latest statistics from Statistics South Africa indicate that the percentage of households in South Africa that have access water increased by $4,2 \%$ (or 4.904 million) from $84,4 \%$ (or 9.448 million) in 2002 to $88,6 \%$ (or 14.352 million) in 2017. The most prominent modalities of access to water are: piped water in the dwelling, piped water on site, a public/ communal tap, and water tanker. Furthermore, the quality of potable water in South African households are perceived as: harmful to their health by $7,7 \%$; cloudy/unclear by $7,4 \%$; unpalatable by $8,6 \%$; and foul-smelling by $6,8 \%$. See Statistics South Africa Statistical Release P0318, General Household Survey 2017 (2019) 35, 40.

21 White Paper para 3.1.4(b) estimated that $48 \%$ of all households did not have access to flush toilets or ventilated improved pit latrines ('VIP toilets') whilst 16\% of all households did not have access to any type of sanitation system in 1994. The latest statistics from Statistics South Africa indicate that the percentage of households in South Africa that have access to sanitation facilities increased by $20,5 \%$ (or 6.409 million) from $61.7 \%$ (or 6.907 million) in 2002 to $82,2 \%$ (or 13.316 million) in 2017. Having access to sanitation is described as being able to use either a flush toilet that is connected to the municipal sewage system or a septic tank, or a VIP toilet. Over the same period the percentage of households in South Africa that do not have access to any sanitation facilities decreased by $9,5 \%$ (or 0.908 million households) from $12,6 \%$ (or 1.410 million households) to $3,1 \%$ (or 0.502 million households). Not having access to sanitation is described as either using a bucket toilet or having no toilet facility at all. This then leaves $14,7 \%$ (or 2.381 million households) of the households in South Africa with access to sanitation services that are somewhere in between the golden standard of a flush toilet and no facility at all. See Statistics South Africa Statistical Release P0318, General Household Survey 2017 (2019) 41-42.

22 The latest statistics from Statistics South Africa indicate that the percentage of households in South Africa that dump or leave their domestic refuse anywhere declined by 3,7\% (or 0.309 million households) between 2002 and 2017 . Over the same period the percentage of households that use their own dump to dispose of their domestic refuse declined by $5,5 \%$ (or 0.731 million households), while the use of communal dumps to dispose of domestic refuse increased marginally by $0,1 \%$ (or 0.166 million households). Where municipalities collect domestic refuse directly from households: those instances where removal takes place less than once per week declined slightly by $0,8 \%$ (or 0.140 million households), while those instances where removal takes place at least once per week increased significantly by $9,8 \%$ (or 4.395 million households). See Statistics South Africa Statistical Release P0318, General Household Survey 2017 (2019) 44.

23 White Paper para 3.1.4(c) estimated that $46.5 \%$ of all households did not have a link to the electricity supply grid in 1994. The latest statistics from Statistics South Africa indicate that the percentage of households in South Africa that are connected to the mains electricity supply increased by 7,7\% (or 5.086 million households) from $76,7 \%$ (or 8.586 million households) in 2002 to $84,4 \%$ (or 13.672 million households) in 2017. See Statistics South Africa Statistical Release P0318, General Household Survey 2017 (2019) 32. 
cooking) ${ }^{24}$ and telecommunication ${ }^{25}$ should be interpreted.

The Constitution states that it is one of the objects of local government to ensure the provision of basic services to communities ${ }^{26}$ in an equitable and sustainable manner. ${ }^{27}$ The power to realise these basic services has been assigned to local governments in terms of two

24 The percentage of households in South Africa that use their connection to the mains electricity supply for cooking increased by $18,4 \%$ (or 5.858 million households) from 57,5\% (or 6.437 million households) in 2002 to $75,9 \%$ (or 12.295 million households) in 2017. As a result there was a simultaneous decline in the percentage of households that use paraffin $(11,9 \%$ or 1.122 million households), wood $(11,6 \%$ or 0.878 million households) and coal $(2,6 \%$ or 0.271 million households). However, the increase in the percentage of people that use gas (2\% or 0.434 million households) for cooking over the same period is an interesting development. See Statistics South Africa Statistical Release P0318, General Household Survey 2017 (2019) 33.

25 The latest statistics from Statistics South Africa indicate that South African households have access to voice telecommunication services as follow: $3,5 \%$ of households (or 0.567 million) do not have access to either a landline or a mobile phone; $0,1 \%$ of households (or 0.162 million) only have access to landlines; $88,2 \%$ of households (or 14.288 million) only have access to a mobile phone; and 8,2\% of households (or 1.328 million) have access to both a landline and a mobile phone. South African households have access to data telecommunication services as follow: $61,8 \%$ of households (or 10.010 million) have access to the internet using all available means while only $10,6 \%$ of households (or 1.717 million) have access to the internet at home. In both modalities the best access is experienced by households in the Western Cape (70,8\% and $25,7 \%$ respectively) and Gauteng $(74 \%$ and $16,5 \%$ respectively), while the worst access in both modalities is experienced in the Eastern Cape (51,8\% and 3,5\% respectively) and Limpopo (43,6\% and 2,2\% respectively). See Statistics South Africa Statistical Release P0318, General Household Survey 2017 (2019) 47-48.

26 Section 152(1)(b), read with section 153, of the Constitution. The range of basic municipal services that a municipality should provide includes, in terms of schedule $4 \mathrm{~B}$ of the Constitution, electricity and gas reticulation; municipal health services; municipal public transport; municipal public works; stormwater management systems in built-up areas; and water and sanitation services limited to potable water supply systems and domestic waste-water and sewage disposal systems. Schedule $5 B$ of the Constitution adds cleansing; local amenities; municipal parks and recreation; municipal roads; refuse removal, refuse dumps and solid waste disposal; and street lighting. However, see the reports of the Auditor-General in terms of the Local Government: Municipal Finance Management Act 56 of 2003 that are available at https://www.agsa.co.za/ Reporting/MFMAReports.aspx. See also K Makwetu 'Constitutional accountability for public resources: The role of the Auditor-General' (2019) 30 Stellenbosch Law Review 318-332; Anonymous 'The shocking state of South Africa's municipalities uncovered' BusinessTech 1 July 2020 https://businesstech.co.za/news/govern ment/412459/the-shocking-state-of-south-africas-municipalities-uncovered/;

Anonymous 'AGs report reveals the municipalities where money goes to waste' Mail and Guardian 2 July 2020 https://mg.co.za/news/2020-07-02-auditorgenerals-report-reveals-the-municipalities-where-the-money-goes-to-waste/; S Shoba 'Municipalities still in financial disarray, audit reveals' Daily Maverick 25 June 2020 https://www.dailymaverick.co.za/article/2020-06-25-munici palities-still-in-financial-disarray-audit-reveals/; and Anonymous 'Auditor-general reveals shocking state of South Africa's municipalities' BusinessTech 26 June 2019 https://businesstech.co.za/news/government/325671/auditor-general-revealsshocking-state-of-south-africas-municipalities/.

27 Section $155(4)$ of the Constitution. 
important statutes: ${ }^{28}$ the Housing Act 107 of $1997^{29}$ ('Housing Act') and the Local Government: Municipal Systems Act 32 of $2000^{30}$ ('Systems Act'). The Constitution and these framework statutes create a 'special cluster of relationships'31 that exist between individuals and the municipalities which are mandated to facilitate access to these services. However, despite the 'public law nature,32 of these services, property law principles play a significant role in obtaining access to statutory utility rights and protecting individuals from unlawful interferences with their use of these services.

28 Section 156(1) and (4) read with sections 155(6) and (7) of the Constitution. See $G$ Muller \& $S$ Liebenberg 'Developing the law of joinder in the context and evictions of people from their homes' (2013) 29 South African Journal on Human Rights 554-570, for a brief overview of these statutes.

29 The long title of the Act states that the purpose of the Act is to facilitate sustainable housing development. Section 1 of the Act defines 'housing development' as 'the establishment and maintenance of habitable, stable and sustainable public and private residential environments to ensure viable households and communities in areas allowing convenient access to economic opportunities, and to health, educational and social amenities in which all citizens and permanent residents of the Republic will, on a progressive basis, have access to - (b) potable water, adequate sanitary facilities and domestic energy supply'. Section 9(1) of the Act imposes a peremptory obligation of local governments to '(a) ensure that - (iii) services in respect of water, sanitation, electricity, roads, stormwater drainage and transport are provided in a manner which is economically efficient' and '(g) provide bulk engineering services, and revenue generating services in so far as such services are not provided by specialist utility suppliers'.

30 The long title of the Act states that the purpose of the Act is to enable local authorities to move progressively towards the social and economic upliftment of communities, and to ensure that these communities obtain universal access to abovementioned basic services. Section 1 of the Act defines 'basic municipal services' as 'a municipal service that is necessary to ensure an acceptable and reasonable quality of life and, if not provided, would endanger public health or safety or the environment.' Section 73(1)(c) of the Systems Act places a peremptory obligation on local governments to ensure that all residents of the community have access to at least the minimum level of basic municipal services. Section 73(2) states that these municipal services must: (a) be equitable and accessible; (b) be provided in a manner that is conducive to (i) the prudent, economic, efficient and effective use of available resources, and (ii) the improvement of standards of quality over time; (c) be financially sustainable; (d) be environmentally sustainable; and (e) be regularly reviewed with a view of upgrading, extending and improving the service.

31 Residents of Joe Slovo Community, Western Cape v Thubelisha Homes 2010 (3) SA 454 (CC) para 343.

32 Joseph $v$ City of Johannesburg 2010 (4) SA 55 (CC). In this case the electricityservice provider that is wholly-owned by the City of Johannesburg, City Power (Pty) Ltd, terminated the electricity supply to the applicants' homes because their landlord owed it a substantial amount of money. The Constitutional Court was asked to consider whether any legal relationship existed between the applicants and City Power, beyond the contractual relationship that existed between City Power and the landlord, and whether that relationship (between service provider and consumer) would entitle the applicants to procedural fairness in terms of s 3(2)(b) of the Promotion of Administrative Justice Act 3 of 2000 (PAJA). 


\section{Statutory utility rights}

\subsection{Water and sanitation}

The Water Services Act 107 of 1998 ('WSA') was enacted to establish a framework within which to regulate all the water services institutions ${ }^{33}$ in South Africa and to provide for access to basic water supply and basic sanitation. ${ }^{34}$ The WSA gives direct effect to the right of access to sufficient water in section 27(1)(b) of the Constitution and the right to the environment in section 24 of the Constitution. The WSA achieves this by imposing peremptory obligations on every water services institution to take reasonable measures to realise these rights $^{35}$ and on all water services authorities ${ }^{36}$ to include the details about the realisation of these rights in its development plans. ${ }^{37}$ Access to these rights must be obtained from a water services provider $^{38}$ and this access is circumscribed by certain conditions, ${ }^{39}$ procedures for the limitation or discontinuation of service, 40 and preferential provision of basic water supply ${ }^{41}$ and basic sanitation ${ }^{42}$ in those circumstances where water services institutions are unable to

33 Long title and preamble of the WSA. Section 1 of the WSA defines 'water services institution' as 'a water services authority, a water services provider, a water board and a water services committee.' See in particular chapter 2 (standards and tariffs); chapter 3 (water service authorities), chapter 4 (water services providers), chapter 5 (water services intermediaries), chapter 6 (water boards), chapter 7 (water services committees), chapter 8 (monitoring and intervention), chapter 9 (financial assistance to water services institutions), chapter 10 (national information system) and chapter 11 (general powers and duties of minister). For more detail about these institutions, see $\mathrm{H}$ Thompson Water law: A practical approach to resource management and the provision of services (2006) 712-722 (water services authorities), 723-736 (water boards), water services providers and water services intermediaries (756-758) and water service committees (736-742).

34 Long title and preamble of the WSA. See, in general, G Muller et al Silberberg and Schoeman's The Law of Property $\left(6^{\text {th }}\right.$ ed) (2019) $772-777$ and Van der Walt (n 16 above) 372-373.

35 Section $3(2)$ of the WSA.

36 Section 1 of the WSA defines 'water services authority' as 'any municipality, including a district or rural council as defined in the Local Government Transition Act 209 of 1993, responsible for ensuring access to water services.'

37 Section 3(3), read with sections $12-18$, of the WSA.

38 See section 6 (for access to water services for domestic use) and section 7 (for access to water services for industrial use) of the WSA.

39 Sections $4(1)$ and (2) of the WSA.

40 Sections $4(3)$ of the WSA.

41 Section 1 of the WSA defines 'basic water supply' as 'the prescribed minimum standard of water supply services necessary for the reliable supply of a sufficient quantity and quality of water to households, including informal households, to support life and personal hygiene.' Regulation 3 of Regulations relating to compulsory national standard and measures to conserve water in GN R509 in GG 22355 (8 June 2001) states that '[t]he minimum standard for basic water supply services is - ... (b) a minimum quantity of potable water of 25 litres per person per day or 6 kilolitres per household per month - (i) at a minimum flow rate of not less than 10 litres per minute; (ii) within 200 metres of a household; and (iii) with an effectiveness such that no consumer is without a supply for more 
meet the needs of all its existing customers. ${ }^{43}$ This regulatory framework enables the promotion and fulfilment of the personal use rights of access to basic water supply and basic sanitation.

The WSA empowers the Minister of Human Settlements, Water and Sanitation - or any water board or water services committee acting with ministerial approval - to expropriate property. ${ }^{44}$ In this regard a local government or a water services provider should furthermore be able to convince the minister to exercise this power if the application is motivated with reference to the Infrastructure Development Act 23 of 2014 ('Infrastructure Act'). Section 5(1) of the Infrastructure Act empowers either the minister or the Presidential Infrastructure Coordinating Commission ${ }^{45}$ ('PICC') to expropriate land or rights in, over or in respect of land for the purpose of implementing ${ }^{46}$ a strategic integrated project. The infrastructure that will support the provision of basic water supply and basic sanitation distribution throughout South Africa has already been designated $^{47}$ as a strategic integrated project. ${ }^{48}$

Once constructed end users will likely obtain access to the water supply and basic sanitation infrastructure from their homes through servitudes $^{49}$ that are registered against the title deeds of their properties. To this end the WSA affords an authorised person three important rights of entry. First, without prior notice, to enter any

42 than seven full days in any year.' This determination was unsuccessfully challenged by the Phiri community of Soweto in Mazibuko $v$ City of Johannesburg (Centre on Housing Rights and Evictions as amicus curiae) 2010 (4) SA 1 (CC). For criticism of this judgment, see $\mathrm{S}$ Liebenberg Socio-economic rights: Adjudication under a transformative constitution (2011) 466-480; $M$ Langford ( $\mathrm{n}$ above) chapter 56B-28, 56B-39; LA Williams 'The justiciability of water rights: Mazibuko $\checkmark$ City of Johannesburg' (2009) 36 Forum for Development Studies 5-48; and $P$ Bond and J Dugard 'The case of Johannesburg water: What really happened at the pre-paid “Parish pump”?' (2008) 12 Law, Democracy and Development 1-28.

42 Section 1 of the WSA defines 'basic sanitation' as 'the prescribed minimum standard of services necessary for the safe, hygienic and adequate collection, removal, disposal or purification of human excreta, domestic wastewater and sewage from households, including informal households.'

43 Section 5 of the WSA.

44 Section 81 of the WSA.

45 Sections 3 and 4, read with section 5(3)(b), of the Infrastructure Act.

46 Section 2(1)(b) of the Infrastructure Act states that one of the objects of this Act is 'the identification and implementation of strategic integrated projects which are of significant economic or social importance to the Republic or a region in the Republic or which facilitate regional economic integration on the African continent, thereby giving effect to the national infrastructure plan.'

47 Section 7(1) of the Infrastructure Act.

48 Section 8(1), read with section 22(1) of the Infrastructure Act. See, specifically 'Sewage works and sanitation', 'Waste infrastructure' and 'Water works and water infrastructure' in Schedule 1 and 'SIP 18: Water and sanitation infrastructure' in Schedule 3 of the Infrastructure Act.

49 Compare section 28(1) of the Sectional Titles Act 95 of 1986 which creates reciprocal implied servitudes in favour of each section over the common property and against any other sections capable of affording this right. See GJ Pienaar Sectional Titles and other fragmented property schemes (2010) 239. These implied servitudes include reciprocal servitudes of lateral and subjacent support 
property $^{50}$ and inspect any water service work ${ }^{51}$ to determine whether the use of water complies with the WSA and its regulations. ${ }^{52}$ Secondly, after the provision of reasonable prior notice, to enter the property to 'repair, maintain, remove or demolish' a water service work; to remove vegetation that interfere with any water service work; to determine the suitability of any water source or site for the construction of a water service work; and 'any activity necessary' for the recovery or measurement of water. ${ }^{53}$ Thirdly, after the provision of reasonable prior notice to an owner or an occupier, to cross the property with the purpose of lawfully entering another property. ${ }^{54} \mathrm{~A}$ water services authority or a water service provider has an obligation to repair 'as far as reasonably possible' any damage caused by the removal of any water service work from property that is not owned by it. ${ }^{55}$ The WSA creates an exception to the principles of accessio in that none of the water service works that are attached to the property of an owner will become their property. ${ }^{56}$ In a further exception, a water service institution may transfer the rights and duties that flow from these rights of entry to another water service institution

and for the passage or provision of certain utilities. Sections 28(1)(a)(ii) and (b)(ii) state that these utilities include water, sewage, drainage, gas, electricity, garbage, artificially heated or cooled air, telecommunication and audio visual services 'through or by means of any pipes, wires, cables or ducts'. These implied servitudes are deemed to be incorporated in the title deeds of the affected sections (Sections 28(2)(a) and 31 of the Act) and afford the owners of these sections reasonable access the affected sections to install new conduits or conduct maintenance and repair works (Section 28(2)(b) of the Act.). Sectional owners are also entitled to the ancillary servitudal rights that may be reasonably necessary for the effective use of these implied servitudes (section 30 of the Act). The Act further provides that sectional owners may, by special resolution, direct the body corporate to create further servitudes that benefit or burden the sectional title scheme (Section 29 of the Act, section 5(1)(g) of the Sectional Titles Schemes Management Act 8 of 2011 and Body Corporate, Seascapes v Ford and Others 2009 (1) SA 252 (SCA)).

50 Section $80(3)$ of the WSA circumscribes this right of entry by stating that a dwelling may only be entered when it is necessary to do so and then only upon reasonable notice and at a reasonable time.

51 Section 1 of the WSA defines a 'water service work' as 'a reservoir, dam, well, pumphouse, borehole, pumping installation, purification work, sewage treatment plant, access road, electricity transmission line, pipeline, meter, fitting or apparatus built, installed or used by a water services institution - (i) to provide water services; (ii) to provide water for industrial use; or (iii) to dispose of industrial effluent'.

52 Section $80(1)$ (a) of the WSA.

53 Section 80(1)(b)(i)-(iv) of the WSA.

54 Section 80(1)(c) of the WSA.

55 Section 79(2)(a) of the WSA.

56 Section 79(1) of the WSA. Compare section 23 of the Electricity Regulation Act 4 of 2006 which creates a similar exception, but elaborates by stating that any auxiliary things that have been attached to the property may not be attached and sold in execution of debt or be subjected to any insolvency or liquidation proceedings; not be subjected to the landlord's tacit hypothec; and only be acted upon with the written consent of the licensee. 
'notwithstanding any law to the contrary' if these rights are explicitly drafted or can be interpreted as personal servitudes. ${ }^{57}$

Whereas the WSA provides the regulatory framework for the provision of water services to consumers flowing from the right to sufficient water, the National Water Act 36 of 1998 ('NWA') aims to dismantle the old dispensation 'relating to control over water and the exercise of traditional or common-law water rights.' 58 NWA was enacted to bring about a pivotal reform in the regulation of water resources ${ }^{59}$ in South Africa. The new regulatory framework is a radical departure from the previous dispensation that was characterised by a distinction between private water (where private ownership vested over certain sources of water) and public water (where personal use rights were primarily acquired from riparian landownership). In the latter instance a user was afforded a 'strongly privileged position' as a result of the close connection between the personal use rights and the riparian landownership. ${ }^{60}$ To this end the purpose of the NWA is to ensure that the scarce and unevenly distributed supply of water in South Africa is used inter alia to meet the needs of present and future generations; promote equitable access to water; redress the result of past discriminatory practices; promote the efficient, sustainable and beneficial use of water in the public interest; ${ }^{61}$ and provide for the growing demand for water use. ${ }^{62}$

57 Section 77(1), read with section 77(2), of the WSA. See section 66 of the Deeds Registries Act 47 of 1937; AJ van der Walt The Law of Servitudes (2016) 458-459; $\mathrm{G}$ Muller et al ( $\mathrm{n}$ above) 382. See also CG van der Merwe 'Can personal servitudes be worded in such a way that they are perpetual in nature and thus freely transferable and transmissible?' 2013 Tydskrif vir die Suid-Afrikaanse Reg 340-348; A Botha 'Die bestaansreg van 'n verjaringstydperk vir persoonlike serwitute ten gunste van regspersone in the Suid-Afrikaanse reg' (1995) 28 De Jure 201-203 and JC Sonnekus 'Oordraagbaarheid en abandonering van persoonlike diensbaarhede' 1987 Tydskrif vir die Suid-Afrikaanse Reg 370-378.

58 G Muller et al ( $\mathrm{n}$ above) 777.

59 Section 1 of the NWA defines a 'water resource' as including 'a watercourse, surface water, estuary, or aquifer' and in turn defines a 'watercourse' as '(a) a river or spring; (b) a natural channel in which water flows regularly or intermittently; (c) a wetland, lake or dam into which, or from which, water flows; and (d) any collection of water which the Minister may, by notice in the Gazette, declare to be a watercourse, and a reference to a watercourse includes, where relevant, its bed and banks', an 'estuary' as 'a partially or fully enclosed body of water - (a) which is open to the sea permanently or periodically; and (b) within which the sea water can be diluted, to an extent that is measurable, with fresh water drained from land', and an 'aquifer' as 'a geological formation which has structures or textures that hold water or permit appreciable water movement through them'.

60 Van der Walt (n 16 above) 373. See further AJ van der Walt 'Overview of developments since the introduction of the constitutional property clause' (2004) 19 Southern African Public Law 85-86 and WJ Vos Principles of South Africa water law $\left(2^{\text {nd }}\right.$ ed) (1978).

61 See A Rabie 'Water for the environment' (1998) 61 Tydskrif vir Hedendaagse Romeins-Hollandse Reg 111-116 and H Klug 'Water law reform under the new Constitution' (1997) 1(5) Human Rights \& Constitutional Law Journal SA 5-10.

62 Section 2(a)-(d) and (f) of the NWA. 
The NWA affords a person the entitlement ${ }^{63}$ to use water ${ }^{64}$ in or from a water resource for 'reasonable domestic use, domestic gardening, [and] fire fighting'. ${ }^{65}$ However, a person may only use water in terms of a general authorisation ${ }^{66}$ or a licence ${ }^{67}$ that was issued to that personal in terms of the NWA. ${ }^{68}$ Furthermore, in what Van der Walt describes as a 'critical' element of the new regulatory framework, ${ }^{69}$ any entitlement granted in terms of the NWA replaces any right to use water that a person might have enjoyed or enforced under 'any other law'.70

The NWA, like the WSA, affords the minister ${ }^{71}$ a broad power to expropriate 'any property for any purpose' that falls within the envisaged ambit of the Act's regulatory framework. ${ }^{72}$ This includes the power to expropriate servitudes of abutment, aqueduct or submersion in chapter 13 of the NWA ${ }^{73}$ and all 'the necessary rights' in land that are required by a person who is under an obligation to

63 Section 1 of the NWA defines 'entitlement' as 'a right to use water in terms of any provision of this Act or in terms of an instrument issued under this Act'.

64 Section 21 of the NWA lists an inclusive list of water uses.

65 Section 4(1) of the NWA. Schedule 1(1) of the NWA elaborates on the permissible uses of water in terms of this section as follows:

'A person may, subject to this Act - (a) take water for reasonable domestic use in that person's household, directly from any water resource to which that person has lawful access; (b) take water for use on land owned or occupied by that person, for - (i) reasonable domestic use; (ii) small gardening not for commercial purposes; and (iii) the watering of animals (excluding feedlots) which graze on that land within the grazing capacity of that land, from any water resource which is situated on or forms a boundary of that land, if the use is not excessive in relation to the capacity of the water resource and the needs of other users; (c) store and use runoff water from a roof; (d) in emergency situations, take water from any water resource for human consumption or fire-fighting; [...] and (f) discharge - (i) waste or water containing waste; or (ii) runoff water, including stormwater from any residential, recreational, commercial or industrial site, into a canal, sea outfall or other conduit controlled by another person authorised to undertake the purification, treatment or disposal of waste or water containing waste, subject to the approval of the person controlling the canal, sea outfall or other conduit.

66 Section 39 of the NWA.

67 Sections $27-55$ of the NWA.

68 Section 4(3), read with section 22(1), of the NWA.

69 Van der Walt (n 16 above) 373.

70 Section 4(4) of the NWA. The section states that this includes ' $(a)$ to take or use water; (b) to obstruct or divert a flow of water; (c) to affect the quality of any water; (d) to receive any particular flow of water; (e) to receive a flow of water of any particular quality; or (f) to construct, operate or maintain any waterwork.' The NWA repealed the whole of the Water Act 54 of 1956.

71 The minister may also authorise a water management institution in writing to expropriate property. However, section 63(2)(b) of the NWA explicitly prohibits the minister from delegating the power to authorise a water management institution to expropriate property.

72 Section 64(1) of the NWA.

73 Section $65(2)$ of the NWA. 
undertake rehabilitation ${ }^{74}$ or other remedial work ${ }^{75}$ on the land of another person but who is unable to obtain access to that land on reasonable terms. ${ }^{76}$ The minister or the PICC may further expropriate land or rights in, over or in respect of land for the purpose of implementing ${ }^{77}$ a strategic integrated project in terms of section 5(1) of the Infrastructure Act. The infrastructure that will support the equitable allocation and sustainable use of water throughout South Africa has already been designated ${ }^{78}$ as a strategic integrated project. $^{79}$

Chapter 13 of the NWA establishes a framework for obtaining access to and rights over land in three parts. Part one empowers an authorised person ${ }^{80}$ to enter or cross property to conduct routine inspections of the use of water; ${ }^{81}$ undertake necessary works and perform various maintenance activities; ${ }^{22}$ and investigate various matters pertaining to the implementation of the Act. ${ }^{83}$ Part 2 affords an authorised person the right to claim $^{84}$ or amend an existing

74 Section 1 of the NWA states that the meaning of 'protection' in relation to a water resource includes 'the rehabilitation of the water resource'. See, in general, chapter 3 of the NWA (protection of water resources). Section $137(2)(d)$ of the NWA specifically requires the national monitoring systems on water resources to collect 'appropriate data and information necessary to assess' the rehabilitation of water resources.

75 Section 53(1) of the NWA empowers a 'responsible authority' to direct an owner or another person who contravenes that Act 'to take any action' specified in a written notice to rectify the contravention. Section 53(2) then empowers the authority to approach a court for relief if the owner or other person fails to comply with the notice. If a court has made a determination about harm, loss or damage in terms of section 152 of the NWA, the court may order that remedial measures must be undertaken by the accused or a water management institution in terms of section 153(c) of the NWA.

76 Section 65(1)(a) of the NWA.

77 Section 2(1)(b) of the Infrastructure Act states that one of the objects of this Act is 'the identification and implementation of strategic integrated projects which are of significant economic or social importance to the Republic or a region in the Republic or which facilitate regional economic integration on the African continent, thereby giving effect to the national infrastructure plan.'

78 Section $7(1)$ of the Infrastructure Act.

79 Section 8(1), read with section 22(1) of the Infrastructure Act. See, specifically 'Sewage works and sanitation', 'Waste infrastructure' and 'Water works and water infrastructure' in Schedule 1 and 'SIP 18: Water and sanitation infrastructure' in Schedule 3 of the Infrastructure Act.

80 Section 124 of the NWA.

81 Section 125(1) of the NWA.

82 Section 125(2) of the NWA. This includes the power to: '(i) clean, repair, maintain, remove or demolish any government waterwork operated by any water management institution; (ii) undertake any work necessary for cleaning, clearing, stabilising and repairing the water resource and protecting the resource quality; (iii) establish the suitability of any water resource or site for constructing a waterwork; (iv) undertake any work necessary to comply with an obligation imposed on any person under this Act, where that person has failed to fulfil that obligation; ( $v$ ) erect any structure and to install and operate any equipment on a temporary basis for monitoring and gathering information on water resources; or (vi) bring heavy equipment on to a property or occupy a property for any length of time.'

83 Section 125(3) of the NWA

84 Section 127(1)(a) of the NWA. 
servitude ${ }^{85}$ of abutment, ${ }^{86}$ aqueduct ${ }^{87}$ or submersion ${ }^{88}$ in terms of a certain procedure. ${ }^{89} \mathrm{An}$ authorised person may claim any of these servitudes as either a praedial or personal servitude 90 and may claim the servitude over an existing waterwork. ${ }^{91}$ A high court has the power to determine and award ${ }^{92}$ just and equitable compensation 93 for the creation of such a servitude. Once awarded the servitude holder has the right to access the land ${ }^{94}$ and obtains expansive effective use rights that must be exercised in a civiliter manner. ${ }^{95}$ However, the holder of the servitude is also under an obligation to maintain the servitude area and effect repairs to the waterworks and access roads during its operation ${ }^{96}$ and to conduct reasonable

85 Section 127(1)(b) of the NWA.

86 Section 126(a) of the NWA defines a 'servitude of abutment' as 'the right to occupy, by means of a waterwork, the bed or banks of a stream or adjacent land belonging to another'.

87 Section 126(b) of the NWA defines a 'servitude of aqueduct' as 'the right to occupy land belonging to another by means of a waterwork for abstracting or leading water'.

88 Section 126(c) of the NWA defines a 'servitude of submersion' as 'the right to occupy land belonging to another by submerging it under water'.

89 Sections 127(4) and 129 of the NWA read with Schedule 2 of the NWA.

90 Section $127(2)$ of the NWA.

91 Section $127(3)$ of the NWA.

92 Section 130 of the NWA.

93 Section 131(1) of the NWA states that the court may, in addition to the factors listed in section 25(3) of the Constitution, also consider the following:

'(a) the nature of the servitude or amendment, including the nature and function of the waterwork relating to the servitude or amendment; (b) whether any existing waterwork will be used to give effect to the servitude; (c) the probable duration of the servitude; (d) the extent of the deprivation of use of the land likely to be suffered as a result of the servitude or amendment; $(e)$ the rental value of the land affected by the servitude or amendment; ( $f$ ) the nature and extent of the actual inconvenience or loss likely to be suffered as a result of the exercise of the rights under the servitude or amendment; (g) the extent to which the land can reasonably be rehabilitated on termination of the servitude; $(h)$ any advantage that the landowner, or other person with a compensatable interest in the land subject to the servitude, is likely to derive as a result of the servitude or amendment; and (i) the public interest served by the waterwork relating to the servitude or amendment.'

94 Section 128(1) of the NWA.

95 Section 128(2) of the NWA. This includes the rights to: '(a) take from the land subject to the servitude, any material or substance reasonably required for constructing, altering, replacing, maintaining or repairing any waterwork or part of a waterwork in respect of which the servitude has been acquired; (b) remove and use vegetation or any other obstacle which is on the land subject to the servitude and which is detrimental to the reasonable enjoyment of the servitude; (c) deposit on the land subject to the servitude any material or substance excavated or removed from the waterwork in the reasonable exercise of the servitude; (d) occupy, during the period of construction of the waterwork in respect of which the servitude has been acquired, as much of the land subject to the servitude as may reasonably be required for - (i) constructing camps or roads; (ii) constructing houses, reservoirs or other buildings or structures; or (iii) installing machinery or equipment, necessary for the construction of the waterwork; (e) occupy, for the duration of the servitude, as much of the land subject to the servitude as is reasonably required for - (i) accommodating people; (ii) workshops; or (iii) storage purposes, to the extent that this is necessary for the control, operation and maintenance of the relevant waterwork.'

96 Sections $128(3)$ and (4) of the NWA. 
rehabilitation of the land upon termination. ${ }^{97}$ Part 3 affords the State and a water management institution the right to retain ownership of a waterwork that was bona fide erected on someone else's land ${ }^{98}$ and the right to remove that waterwork from the land. ${ }^{99}$ The NWA creates an explicit exception which permits the transfer of personal servitudes in waterworks held by the Minister of Water and Sanitation or a water management institution. ${ }^{100}$

\section{$2.2 \quad$ Electricity}

The Electricity Regulation Act 4 of 2006 ('ERA') was enacted to establish a regulatory framework for the generation, distribution ${ }^{101}$ and trading of electricity; to designate the National Energy Regulator of South Africa ${ }^{102}$ ('Nersa') as the custodian and administrator of this regulatory framework; ${ }^{103}$ and to enumerate the electricity reticulation duties of municipalities to end users. ${ }^{104}$ The focus of the ERA's regulatory framework is inter alia to facilitate universal access to electricity; ${ }^{105}$ to ensure that the electricity interests and needs of end users is protected; ${ }^{106}$ and to achieve the development and operation of electricity supply infrastructure in South Africa. ${ }^{107}$

The ERA, unlike the WSA and the NWA, does not give direct effect to a right in the Bill of Rights. Instead, the ERA indirectly gives effect to section 152(1)(b), read with schedule 4B, of the Constitution in that it enables the promotion and fulfilment of the personal use right of access to electricity. The ERA achieves this by imposing peremptory obligations on local governments to inter alia to provide basic reticulation services 'free of charge or at a minimum cost', within its available resources, to certain classes of end users ${ }^{108}$ and invest appropriately in its electricity infrastructure so that it can ensure 'access' to these services on a progressive basis. ${ }^{109}$

97 Section $128(5)$ of the NWA.

98 Section 135(1)(a) of the NWA.

99 Section 135(1)(b) and (2) of the NWA.

100 Section 136 of the NWA.

101 The definition of 'distribution' and 'transmission' in section 1 of the ERA is identical but for the distinction that is made in terms of the conveyance of electricity below $132 \mathrm{kV}$ for distribution power systems and above $132 \mathrm{kV}$ for transmission power systems.

102 See chapter 2 of the ERA and chapter 2 of the National Energy Regulator Act 40 of 2004.

103 Sections 7-21 of the ERA.

104 The definition of 'customer' and 'end user' in section 1 of the ERA is identical but for the distinction that the former purchases the electricity and/or service and the latter uses the electricity and/or service. We will use 'end user' to refer to both unless the context specifically indicates otherwise.

105 Section 2(d) of the ERA.

106 Section 2(b) of the ERA.

107 Section $2(a)$ of the ERA.

108 Section 27(e) of the ERA.

109 Section $27(\mathrm{~d})$ of the ERA. 
Licensees may be confronted with the problem of acquiring appropriate land or rights in, over or in respect of land that will enable it to build the infrastructure and roll out these services to a larger number and wider range of end users throughout South Africa in the congested spatial makeup of integrated municipal development. The ERA anticipates this problem and empowers the Minister of Public Works to expropriate such land or rights in, over or in respect of land. ${ }^{110}$ However, the minister may only exercise this power if the licensee is unable to acquire the land from the current owner in terms of an agreement ${ }^{111}$ and if it reasonably requires that specific land or rights in, over or in respect of land 'for facilities which will enhance the electricity infrastructure in the national interest'. ${ }^{112}$ In this regard a licensee should be able to convince the minister to exercise this power if the application is motivated with reference to the Infrastructure Development Act 23 of 2014 ('Infrastructure Act'). Section 5(1) of the Infrastructure Act empowers either the minister or the Presidential Infrastructure Coordinating Commission ${ }^{113}$ ('PICC') to expropriate land or rights in, over or in respect of land for the purpose of implementing ${ }^{114}$ a strategic integrated project. The infrastructure that will support electricity distribution throughout South Africa has already been designated ${ }^{115}$ as a strategic integrated project. ${ }^{116}$

Once constructed end users will likely obtain access to the electricity infrastructure from their homes through servitudes ${ }^{117}$ that are registered against the title deeds of their properties. To this end

110 Section 26(1) of the ERA and Electricity Regulations for Expropriating on behalf of a Licensee Government Notice R147 in Government Gazette 30754 of 8 February 2008.

111 Section 26(3)(a) of the ERA and Regulation 2(2)(a), (b), (f) and (h).

112 Section 26(3)(b) of the ERA and Regulation 2(2)(c) and (d).

113 Sections 3 and 4, read with section 5(3)(b), of the Infrastructure Act.

114 Section 2(1)(b) of the Infrastructure Act states that one of the objects of this Act is 'the identification and implementation of strategic integrated projects which are of significant economic or social importance to the Republic or a region in the Republic or which facilitate regional economic integration on the African continent, thereby giving effect to the national infrastructure plan.'

115 Section $7(1)$ of the Infrastructure Act.

116 Section 8(1), read with section 22(1) of the Infrastructure Act. See, specifically 'Electricity transmission and distribution' in Schedule 1 and 'SIP 10: Electricity transmission and distribution for all' in Schedule 3 of the Infrastructure Act. See also section 34 of the ERA and 'Power stations or installations for harnessing any source of energy' in Schedule 1 and 'SIP 8: Green energy in support of the South African economy' and 'SIP 9: Electricity generation to support socio-economic development' in Schedule 3 of the Infrastructure Act. See further 'SIP 20: Energy' in GN 812 GG 43547 of 24 July 2020.

117 Compare section 28(1) of the Sectional Titles Act 95 of 1986 which creates reciprocal implied servitudes in favour of each section over the common property and against any other sections capable of affording this right. See Pienaar (n 49 above) 239. These implied servitudes include reciprocal servitudes of lateral and subjacent support and for the passage or provision of certain utilities. Sections 28(1)(a)(ii) and (b)(ii) state that these utilities include water, sewage, drainage, gas, electricity, garbage, artificially heated or cooled air, telecommunication and audio visual services 'through or by means of any pipes, wires, cables or ducts'. 
section 22(1) of the ERA empowers an authorised person to 'at all reasonable times' enter ${ }^{118}$ a premises where electricity is supplied to: (a) determine the quantity of electricity consumed; (b) inspect the 'lines, meters, fittings, works or apparatus' that belong to the licensee; ${ }^{119}$ or (c) remove any of these auxiliary things where the electricity supply is no longer required or where the licensee may terminate the supply. This right of entry includes the right to do whatever is necessary to carry out its licenced activities 'over, in or along roads or streets and associated infrastructure'. ${ }^{20}$ However, in doing so a licensee must comply with all applicable laws and by-laws and complete its works within a reasonable time. ${ }^{121}$ The licensee has an obligation to repair any damage caused by the entry, inspection or removal of the auxiliary things or compensate the owner of the premises. ${ }^{122}$ Section 23(1) of the ERA creates an exception to the principles of accessio in that none of the auxiliary things that are attached to the land or premises of an owner or the municipality will become their property. These auxiliary things may therefor: not be attached and sold in execution of debt or be subjected to any insolvency or liquidation proceedings; not be subjected to the landlord's tacit hypothec. ${ }^{123}$ and only be acted upon with the written consent of the licensee. ${ }^{124}$

\subsection{Telecommunication}

The Electronic Communications Act 36 of 2005 ('ECA') was enacted to establish a regulatory framework ${ }^{125}$ to inter alia promote convergence amongst various information technology sectors; and to regulate electronic communication services $^{126}$ and electronic

118 Section 22(2) of the Act details peremptory protocols for the entry of any premises.

119 Section 33 (1)(a) of the Act extends this right to a person authorised by the National Energy Regulator.

120 Section 24(1)(a) of the Act. Section 24(1)(b) of the Act makes this right subject to supervision.

121 Section 24(2)(a) and (b) of the Act.

122 Section 22(3) of the ERA. See further section 24(2)(c) of the Act.

123 See R Brits Real Security Law (2016) 435-478, S Viljoen The Law of Landlord and Tenant (2016) 311-344, NS Siphuma The lessor's tacit hypothec: A constitutional analysis (unpublished LLM thesis, Stellenbosch University, 2013) and Muller et al (n above) 520-525.

124 Section $23(2)(a)-(c)$ of the ERA.

125 Long title of the ECA.

126 Section 1 of the ECA defines 'electronic communications service' as 'any service provided to the public, sections of the public, the State, or the subscribers to such service, which consists wholly or mainly of the conveyance by any means of electronic communications over an electronic communications network, but excludes broadcasting services.' 
communication network services. ${ }^{127}$ The primary objective of this regulatory framework is to, in the public interest, promote: the provision of a variety of quality services at reasonable prices; ${ }^{128}$ the interests of consumers with regard to the price, quality and the variety of these services; ${ }^{129}$ an environment of open, fair and nondiscriminatory access to these services and broadcasting services; ${ }^{130}$ and the universal provision and connectivity to these services. ${ }^{131}$

The ECA, unlike the WSA and the NWA, does not give direct effect to a right in the Bill of Rights. Instead, the ECA indirectly gives effect to section 32 of the Constitution in that it enables the promotion and fulfilment access to information as a personal use right. The Universal Service and Access Agency of South Africa ${ }^{132}$ ('Agency') was established to promote the goal of universal access to telecommunication services and to encourage, facilitate and offer guidance on any scheme that aims to achieve this goal. ${ }^{133}$ To fulfil this mandate the Agency must conduct research into and keep abreast of developments on information communication technology, services and facilities and must continually evaluate the extent to which the goal of universal access have been achieved in South Africa. ${ }^{134}$ The Agency may also conduct investigations into matters relating to its mandate and may issue information about the extent of access and provision of information communication technology, services and facilities in South Africa. ${ }^{135}$

Licensees may be confronted with the problem of acquiring appropriate land or rights in, over or in respect of land that will enable it to build the infrastructure and roll out these services to a larger number and wider range of end users throughout South Africa in the congested spatial makeup of integrated municipal development. Unlike the WSA and the ERA, the ECA does not explicitly empower the minister to expropriate land or rights in, over or in respect of land for this purpose. However, the Agency is empowered to 'foster the adoption and use of new methods of attaining universal

127 Section 1 of the ECA defines 'electronic communications network service' as ' $a$ service whereby a person makes available an electronic communications network, whether by sale, lease or otherwise - (a) for that person's own use for the provision of an electronic communications service or broadcasting service; (b) to another person for the other person's use in the provision of an electronic communications service or broadcasting service; or (c) for resale to an electronic communications service licensee, broadcasting service licensee or any other service contemplated by this Act.'

128 Section $2(m)$ of the ECA.

129 Section $2(n)$ of the ECA.

130 Section 2 (g) of the ECA.

131 Section 2(c) of the ECA. See the definitions of 'universal access' and 'universal service' in section 1 of the ECA.

132 Visit its website at http://Www.usaasa.org.za for more information about its leadership, projects, resources and tenders.

133 Section 82(1)(a) and (b)(i) of the ECA.

134 Section 82(4)(b) and (c) of the ECA.

135 Section $82(4)(a)$ and (d) of the ECA. 
access and universal service,136 and could use its expertise to recommend to the Minister of Communication ${ }^{137}$ or advise the Independent Communications Authority of South Africa ${ }^{138}$ ('Icasa') that land or rights in, over or in respect of land should be expropriated to promote the goal of universal access and universal service. A licensee would likely be able to successfully motivate that the minister or the PICC exercise their expropriation power in terms of section 5(1) of the Infrastructure Act. The infrastructure that will support the roll out of communication services and information technology installations throughout South Africa has already been designated as a strategic integrated project. ${ }^{139}$ Following the expropriation the resources in the Universal Service and Access Fund may be used to subsidise the construction of the required infrastructure in underserviced areas. ${ }^{140}$

With the infrastructure in place the rollout of the services to the end users can commence. The resources in the Universal Service and Access Fund may also be used in these circumstances to subsidise the costs involved with the provision or use of these services for people in need. ${ }^{141}$ The ECA also empowers the minister to develop a policy for the rapid deployment and provisioning of electronic communications facilities. ${ }^{142}$ Icasa must then prescribe regulations that establish procedures and processes for resolving disputes that may arise between a landowner and an electronic communications network service licensee. ${ }^{143}$ In this regard section 22(1) of the ECA affords a network service licensee three important rights. First, the right to enter any land, railway or waterway. ${ }^{144}$ Second, the right to construct and maintain an electronic communications network or facility on any land, railway or waterway. ${ }^{145}$ This right has three ancillary rights: (a) the right to construct and maintain pipes, tunnels or tubes under any street; ${ }^{146}$ (b) the right to erect and maintain a gate in a fence that

136 Section $82(1)(c)$ of the ECA.

137 Section $82(3)$ and $(4)(e)$ of the ECA.

138 Section 82(4)(f) of the ECA.

139 Section 8(1), read with section 22(1) of the Infrastructure Act. See, specifically 'Communication and information technology installations' in Schedule 1 and 'SIP 15: Expanding access to communication technology' in Schedule 3 of the Infrastructure Act. See also 'SIP 22: Digital Infrastructure' in GN 812 GG 43547 of 24 July 2020.

140 Section 88(1)(b), read with section 88(2), of the ECA.

141 Section 88(1)(a) of the ECA.

142 Section 21(1) of the ECA.

143 Section 21(2)(b) of the ECA.

144 Section 22(1)(a) of the ECA.

145 Section 22(1)(b) of the ECA.

146 Section 24(1)(a) of the ECA. A local authority has a similar power to install conduit pipe for underground cables from a point of connection on the street boundary to a building on a premises in terms of section 23 of the ECA. 
would otherwise preclude the licensee entry or inconvenience the licensee's right to enter; ${ }^{147}$ and (c) the right to fell or prune any tree or vegetation that obstructs or interferes with the operation and maintenance of an electronic network communications network or facility. ${ }^{148}$ Last, a network service licensee has the right to alter an electronic communications network or facility by attaching wires or struts to any building or structure, or remove such network or facility. ${ }^{149}$ Any alteration or removal may be necessitated by a misalignment or an uneven surface, or the commencement of building works by a local authority or a private person. ${ }^{150}$ In exercising all these rights the licensee must have due regard 'to applicable law', 151 and the environmental policy of South Africa. ${ }^{152}$

\section{Conclusion}

The preceding analysis reveals that a suite of statutes - comprising the WSA, NWA, ERA and ECA - has been enacted since 1994 to establish a new regulatory framework within which obtaining access to services like water, sanitation, electricity and telecommunication can be promoted and fulfilled. The WSA and the NWA gives direct effect to the right to the environment in section 24 of the Constitution and to the right of access to the sufficient water in section 27(1)(b) of the Constitution. The ERA, on the other hand, indirectly gives effect to a specific function of local government in section 152(1)(b), read with schedule $4 \mathrm{~B}$, of the Constitution while the $\mathrm{ECA}$ gives indirect effect to the right of access to information in section 33 of the Constitution. Collectively the suite of statutes affords individuals personal use rights to access water and sanitation, electricity and telecommunication.

147 Section 26(1)(a) of the ECA. The licensee must also provide a set of duplicate keys to the owner or occupier of the land in terms of section 26(1)(b) of the ECA.

148 Section 27(1) of the ECA.

149 Section 22(1)(c) of the ECA. Compare section 28(1) of the Sectional Titles Act 95 of 1986 which creates reciprocal implied servitudes in favour of each section over the common property and against any other sections capable of affording this right. See Pienaar (n above) 239. These implied servitudes include reciprocal servitudes of lateral and subjacent support and for the passage or provision of certain utilities. Sections 28(1)(a)(ii) and (b)(ii) state that these utilities include water, sewage, drainage, gas, electricity, garbage, artificially heated or cooled air, telecommunication and audio visual services 'through or by means of any pipes, wires, cables or ducts'.

150 Section 25 of the Act.

151 In Tshwane City v Link Africa 2015 (11) BCLR 1265 (CC) paras 150-155 the court held that 'applicable law' included various principles of the common law of servitudes. In Dark Fibre Africa (Pty) Ltd v Cape Town City 2018 (4) SA 185 (WCC) the court held further that 'applicable law' also included levies in terms of section 75A(1)(a) of the Local Government: Municipal Systems Act 32 of 2000 and conditions that were imposed on the applicant in terms of the local authority's street by-law.

152 Section 22(2) of the Act. 
The various service providers may, however, be confronted with the problem of acquiring appropriate land that will enable it to build the infrastructure and roll out these services throughout South Africa in the congested spatial makeup of integrated municipal development. To this end the WSA, NWA and ERA explicitly afford the respective ministers the power to expropriate land or rights in, over or in respect of land that will enable the service providers to build the required infrastructure. However, the ECA does not explicitly afford the minister this power. Instead the Agency is empowered to 'foster the adoption and use of new methods of attaining universal access and universal service' and should use its expertise to recommend to the minister or advise Icasa that land or rights in, over or in respect of land should be expropriated to promote the goal of universal access and universal service. Additionally, the various service providers would likely be able to successfully motivate that the respective ministers or the PICC exercise their expropriation power in terms of section 5(1) of the Infrastructure Act. The infrastructure that will support the roll out of basic water supply and sanitation, support the equitable allocation and sustainable use of water, support electricity distribution and promote communication services and information technology installations throughout South Africa has already been designated as a strategic integrated project in Schedules 1 and 3 of the Infrastructure Act.

The suite of statutes also explicitly recognises a range of nonconsensual servitudes that permit service providers to enter and inspect property with or without reasonable prior notice; to conduct repair and various maintenance works; to remove installations and vegetation that interfere with the operation of the installations with the consequent obligation to repair any damage that may have been effected to the property in the process; and to demolish installations. The ERA and the WSA also create explicit exceptions to the principles of accessio to the extent that the installations which have been affixed to buildings in terms of these statutes do not attach to the land and thereby become the property of the owner through the operation of law. In a further set of exceptions both the WSA and the NWA permit the transfer of personal servitudes (of entry and waterworks respectively) to another organ of state.

The regulatory framework - comprising distinct property principles of personal use rights, expropriation and servitudes - that the suite of statutes establishes to obtain access to these services should be interpreted as positive measures in terms of section 26(2) of the Constitution that have been enacted to progressively realise the right of access to adequate housing in section 26(1) of the Constitution. The suite of statutes has the transformative potential of facilitating access to these services for a larger number and wider range of individuals throughout South Africa. However, despite this transformative potential, the right of access to adequate housing also 
contains a negative obligation 'to desist from preventing or impairing, 153 the access that individuals currently have to these services. Property principles can protect the use of these services with a possessory remedy known as the spoliation remedy.

153 Grootboom para 34. 